Article

\title{
Bioinformatics and Transcriptional Study of the Nramp Gene in the Extreme Acidophile Acidithiobacillus ferrooxidans Strain DC
}

\author{
Bo Miao ${ }^{1,2}$, Li Shen ${ }^{1,2}$, Xueduan Liu ${ }^{1,2}$, Weimin Zeng ${ }^{1,2}$ and Xueling Wu ${ }^{1,2, *}$ \\ 1 School of Minerals Processing and Bioengineering, Central South University, Changsha 410083, China; \\ miaobo@csu.edu.cn (B.M.); lishen@csu.edu.cn (L.S.); xueduanliu@csu.edu.cn (X.L.); \\ zengweimin@csu.edu.cn (W.Z.) \\ 2 Key Laboratory of Biometallurgy of Ministry of Education, Central South University, \\ Changsha 410083, China \\ * Correspondence: wxlcsu@csu.edu.cn; Tel.: +86-0731-8887-7472
}

Received: 30 April 2020; Accepted: 13 June 2020; Published: 16 June 2020

\begin{abstract}
The family of Nramp (natural resistance-associated macrophage protein) metal ion transporter functions in diverse organisms from bacteria to humans. Acidithiobacillus ferrooxidans (At. ferrooxidans) is a Gram-negative bacterium that lives at $\mathrm{pH} 2$ in high concentrations of soluble ferrous ion $(600 \mathrm{mM})$. The AFE_2126 protein of At. ferrooxidans of the Dachang Copper Mine (DC) was analyzed by bioinformatics software or online tools, showing that it was highly homologous to the Nramp family, and its subcellular localization was predicted to locate in the cytoplasmic membrane. Transcriptional study revealed that AFE_2126 was expressed by $\mathrm{Fe}^{2+}$-limiting conditions in At. ferrooxidans DC. It can be concluded that the AFE_2126 protein may function in ferrous ion transport into the cells. Based on the $\Delta \mathrm{pH}$ of the cytoplasmic membrane between the periplasm ( $\mathrm{pH}$ 3.5) and the cytoplasm ( $\mathrm{pH}$ 6.5), it can be concluded that $\mathrm{Fe}^{2+}$ is transported in the direction identical to that of the $\mathrm{H}^{+}$gradient. This study indirectly confirmed that the function of Nramp in At. ferrooxidans DC can transport divalent iron ions.
\end{abstract}

Keywords: acidophilic bacterium; AFE_2126; Nramp family; metal ion transporters; magnetic nanoparticles; multireference genes

\section{Introduction}

NRAMP comprises a cluster of highly conserved integral membrane proteins and exists widely in bacteria, archaea, fungi, plants, animals, and humans [1-6]. The NRAMP family is a novel family of functionally related proteins defined by a conserved hydrophobic core of ten transmembrane domains [1]. Rodents and humans express two paralogous genes related to iron imbalance and immune diseases [7]. Nramp1 is an integral membrane protein, expressed only in cells of the immune system, and plays a significant role in the membrane of the phagosome during phagocytosis [8]. Nramp2 is a multivalent divalent cation transporter such as $\mathrm{Fe}^{2+}, \mathrm{Mn}^{2+}$, and $\mathrm{Zn}^{2+}$ [9]. It is highly expressed in the intestine and is the major iron uptake system in mammals that do not depend on transferrin. The yeast proteins Smf1p and Smf2p may also transport divalent cations [10]. The natural resistance of mice to infection by intracellular parasites is controlled by the Bcg locus [11], which regulates the cytostatic/cytocidal activity of phagocytes. AtNRAMP1, AtNRAMP3, and AtNRAMP4 encode functional plant metal transporters [12] and are expressed at higher levels when the low iron content in plants is low $[13,14]$. In contrast, using semiquantitative reverse transcription PCR (semi-Q-RT-PCR), Agranoff et al. [15] suggested that the Nramp mRNA levels in M. tuberculosis will increase with the increases of surrounding $\mathrm{Fe}^{2+}$. Other transporter proteins from multiple 
sources also belong to this family. After a bioinformatics analysis, the Mn (II)/Fe(II) NRAMP transporter was found in biomining acidophiles [16,17], but it was not detected in Leptospirillum spp. [17]. Using semi-Q-RT-PCR, Potrykus et al. [18] found that two species from the Ferroplasma genus displayed opposite trends. Under iron-limiting conditions, the gene-encoding NRAMP transporter was downregulated in "Ferroplasma Acidarmanus" Fer1 and upregulated in Ferroplasma acidiphilum $\mathrm{Y}^{\mathrm{T}}$.

Bioleaching is an established technology to extract base and precious metals from sulfide minerals by using the acidophiles that have the capacities to oxidize ferrous iron and/or sulfur [19]. At. ferrooxidans (formerly Thiobacillus ferrooxidans) is the dominant bacteria used in bioleaching to recover metals [20-24]. It is an acidophilic, chemolithotrophic $\gamma$-proteobacterium that can grow aerobically by oxidizing ferrous iron to ferric iron in the outer membrane [25], or sulfur (and reduced sulfur compounds) to sulfuric acid, as its energy source [26,27]. However, iron is an essential micronutrient for almost all organisms, including At. ferrooxidans, due to its redox properties. Given its limited bioavailability, most microorganisms have developed complicated mechanisms to remove this metal from their environment [28]. On the other hand, the redox properties of iron will also convert it into biotoxicity when it is over-acquired. Bacteria have developed strict intracellular homeostasis controls to balance the absorption storage of iron in response to possible oxidative stress [29].

Two primary iron forms are found on the Earth: $\mathrm{Fe}^{3+}$ in the aerobic atmosphere and $\mathrm{Fe}^{2+}$ in reducing intracellular environments. Bacteria have developed a series of strategies for obtaining iron, including both $\mathrm{Fe}^{2+}$ and $\mathrm{Fe}^{3+}$-specific transporters [30]. $\mathrm{Fe}^{2+}$ is sufficiently soluble in bacteria, that it can be transported through porins in the outer membrane and then into the cytoplasm by FeoB (Ferrous iron transport protein B) [30]. Bacteria and fungi synthesize quantities of low molecular weight iron ligands called siderophores, which are secreted into the extracellular medium, where they bind $\mathrm{Fe}^{3+}$ with high affinity [31]. Adding ferric ions $\left(\mathrm{Fe}^{3+}\right)$ to the medium can alleviate the toxicity of heavy metals to microorganisms [32]. The pathway for $\mathrm{Fe}^{3+}$-dicitrate uptakes may be mediated by the FecA (Ferric citrate uptake A) outer membrane protein, a periplasmic-binding protein (PBP) and FecDE (FecD (Ferric citrate uptake D) and FecE (Ferric citrate uptake E)) [30]. The transport of bound chelates across the outer membrane depends on TonB-ExbB-ExbD. This cytoplasmic membrane-localized complex transduces energy from the proton motive force to high-affinity receptors in the outer membrane [30].

The role of iron transport into cells is involved in important metabolic activities in the cell (such as cellular respiration, photosynthesis, and DNA synthesis, which require the participation of iron-containing metalloenzymes), and magnetotactic bacteria can synthesize some magnetic nanoparticles (magnetosomes). Ferrous sulfate is essential for the synthesis of magnetosomes in At. ferrooxidans $[33,34]$. The magnetosome is coated by a biofilm and synthesized under the control of cells. It is a new type of biological source magnetic nanomaterial. Its role is to serve as a functional material for the orientation and navigation of microorganisms. Magnetosomes are also products of microbial mineralization, which can produce a large amount of magnetite $\left(\mathrm{Fe}_{3} \mathrm{O}_{4}\right)$ and greigite $\left(\mathrm{Fe}_{3} \mathrm{~S}_{4}\right)$ per year [35]. Su et al. [36] found that $\mathrm{Fe}_{3} \mathrm{O}_{4}$ can be a good precursor for fabricating nanomaterials applied in energy storage systems.

The purposes of this study are to understand the partial mechanisms by which At. ferrooxidans of the Dachang Copper Mine (DC) processes iron uptake and homeostasis in the presence of an abnormally abundant supply of $\mathrm{Fe}^{2+}$ in an acid environment. The function of NRAMP has been investigated in many microorganisms. However, there are few researches on its function in At. ferrooxidans DC. This deficiency motivated the study reported herein.

\section{Materials and Methods}

\subsection{Bacterial Strains and Growth Conditions}

The native At. ferrooxidans strain DC (gi:209405433) was isolated from the Dachang Copper Mine (DC), Guangxi Province, China [37]. At. ferrooxidans DC was grown under aerobic conditions (170 rpm) at $30^{\circ} \mathrm{C}$ in 9-K basal salt medium [38] (per liter: $3.0 \mathrm{~g}\left(\mathrm{NH}_{4}\right)_{2} \mathrm{SO}_{4}, 0.1 \mathrm{~g} \mathrm{~K} \mathrm{Cl}, 0.5 \mathrm{~g} \mathrm{~K}_{2} \mathrm{HPO}_{4}$, 
$0.5 \mathrm{~g} \mathrm{MgSO}_{4} \cdot 7 \mathrm{H}_{2} \mathrm{O}$, and $\left.0.01 \mathrm{~g} \mathrm{Ca}\left(\mathrm{NO}_{3}\right)_{2}\right)$ containing sulfur $\left(9 \mathrm{~K}+\mathrm{S}\left(9 \mathrm{~K}_{\mathrm{s}}\right): 0.8 \%(\mathrm{~g} / \mathrm{L})\right.$ filter-sterilized sulfur adjusted to $\mathrm{pH} 2.2$ with $\mathrm{H}_{2} \mathrm{SO}_{4}$ ). Based on the research purpose, the $9-\mathrm{K}_{\mathrm{s}}$ medium was modified as follows: $9 \mathrm{~K}_{\mathrm{s}}+\mathrm{Fe}^{2+}: 1,10,100,300$, and $600 \mathrm{mM} \mathrm{FeSO}_{4} \cdot 7 \mathrm{H}_{2} \mathrm{O}$.

\subsection{Growth Curves}

Media $\left(9 \mathrm{~K}_{\mathrm{s}}+\mathrm{Fe}^{2+}\right)$ was inoculated with fresh mid-exponential-phase cells of At. ferrooxidans DC pregrown in $9 \mathrm{~K}_{\mathrm{s}}+\mathrm{Fe}^{2+}$ and incubated at $30{ }^{\circ} \mathrm{C}$. Samples were taken every day and counted in a Petroff-Hausser counting chamber under a phase-contrast microscope at 400× magnification. The number of cells per milliliter was plotted against the incubation time. All experiments were conducted at least twice, with two to three repetitions for each treatment.

\subsection{Cell Collection}

Before collecting the cells, At. ferrooxidans DC cultures for nucleic acid were centrifuged at $4500 \times g$ to remove iron precipitates. The cell pellet was resuspended in $9-\mathrm{K}$ salt solution for further use. The washed cells were collected by centrifugation at $12,000 \times \mathrm{g}$ for $10 \mathrm{~min}$. To reach the same number of the cells before RNA was extracted from different samples, the concentration of each sample was calculated according to the standard curve at $\mathrm{A}_{600}$. Then, the corresponding volume was taken to reach $5 \times 10^{8}$ cells.

\subsection{General DNA Techniques}

Genomic DNA was extracted from At. ferrooxidans DC by the manufacturers of the reagents (Tiangen Biotech, Beijing, China). Oligonucleotide primers (F1: 5'-GATGTCAATGTATGCCACGC-3' and R1: $5^{\prime}$-TATCCTCTATCGCCGCAATT- $3^{\prime}$ ) used in this study and PCR was performed using a $25-\mu \mathrm{L}$ PCR reaction system and conditions comprising a denaturation step of $3 \mathrm{~min}$ at $95^{\circ} \mathrm{C}$, followed by 30 amplification cycles (denaturation for $45 \mathrm{~s}$ at $95^{\circ} \mathrm{C}$, annealing for $45 \mathrm{~s}$ at $60^{\circ} \mathrm{C}$, and elongation for $90 \mathrm{~s}$ at $72{ }^{\circ} \mathrm{C}$ ) and a final elongation step at $72{ }^{\circ} \mathrm{C}$ for $10 \mathrm{~min}$. Each PCR reaction contained a 2-ng template DNA, 1- $\mu \mathrm{M}$ required primers, and $0.2-\mathrm{mM}$ each deoxyribonucleotide in a volume of $25 \mu \mathrm{L}$ of $2 \times \mathrm{PCR}$ mix containing $1.5-\mathrm{mM} \mathrm{MgCl}_{2}$ (Tiangen). The At. ferrooxidans DC Nramp coding region was amplified from chromosomal DNA preparations with a forward primer (F1) and reverse primer (R1). PCR product was purified from agarose gels with a DNA purification kit (Tiangen Biotech, Beijing, China) and sequenced by Sangon Biotech (Shanghai, China).

\subsection{RNA Extraction and Reverse Transcription Quantitative Real-Time PCR (RT-qPCR)}

Total RNA was extracted from At. ferrooxidans DC grown to the mid-exponential phase in 9- $\mathrm{K}_{\mathrm{s}}$ medium in the presence of ferrous ion $\left(\mathrm{Fe}^{2+}: 1,10,100,300\right.$, and $\left.600 \mathrm{mM}\right)$ using the RNAprep Pure Cell/Bacteria Kit (Tiangen Biotech, Beijing, China) according to manufacturer instructions. Then, the RNA was immediately inversed-transcribed to the cDNA in a volume of $20 \mu \mathrm{L}$ by a Quantscript RT Kit (Tiangen Biotech, Beijing, China). One microgram of total RNA was used for each reaction. The RNA integrality was evaluated by $2.0 \%$ agarose gel electrophoresis, and its purity and ratio of absorbance at $260 \mathrm{~nm}$ to $280 \mathrm{~nm}$ (A260/A280 ratio) were measured with the NanoDrop ${ }^{\circledR} \mathrm{ND}-1000$ Spectrophotometer (NanoDrop Technologies, Montchanin, DE, USA). RNA was temporarily stored at $-80^{\circ} \mathrm{C}$, and the resulting cDNA was stored in aliquots at $-20^{\circ} \mathrm{C}$ until further use.

The integrity of the total cellular RNA was checked by formaldehyde agarose gel electrophoresis and ethidium bromide staining. The definition of the $23 \mathrm{~S}$ and $16 \mathrm{~S}$ bands was very high, and the luminance ratio between $23 \mathrm{~S}$ and $16 \mathrm{~S}$ was 2/1. The A260/A280, which was quantified with the NanoDrop ${ }^{\circledR}$ ND-1000 Spectrophotometer (NanoDrop Technologies, Montchanin, DE, USA), was about 1.75-2.0. These results indicated that the purity and integrity of the total cellular RNA was sufficient for this study.

To confirm that the RNA does not contain DNA, only RNA was used as a negative control in qPCR with other samples. The negative control did not produce a fluorescence signal, indicating 
that the RNA was not contaminated with DNA. The melt curve had only one peak, so there was no nonspecific product or primer dimer in the PCR products.

Primers for RT-qPCR assays [39] and amplicon size are listed in Table 1. The real-time PCR reactions were performed in the iCycler iQ real-time PCR detection system (Bio-Rad) using the RealMasterMix SYBR Green Kit (Tiangen Biotech, Beijing, China). Each $25-\mu \mathrm{L}$ reaction contained $1 \mu \mathrm{L}$ of cDNA template, $12.5 \mu \mathrm{L}$ of real master mix, including the SyberGreen I fluorescent dye, enabling the monitoring of the PCR amplification, and the gene-specific primer pair at a final concentration of $200 \mathrm{nM}$ for each primer. The cycling protocol was as follows: initial denaturation for $3 \mathrm{~min}$ at $95^{\circ} \mathrm{C}$, followed by 40 cycles of $15 \mathrm{~s}$ at $95^{\circ} \mathrm{C}, 20 \mathrm{~s}$ at $59^{\circ} \mathrm{C}$, and $35 \mathrm{~s}$ at $68^{\circ} \mathrm{C}$. Fluorescence was measured after the extension phase at $68^{\circ} \mathrm{C}$. The PCR products were subjected to a melting curve analysis, which was followed by 80 consecutive cycles of $55^{\circ} \mathrm{C}$ for $10 \mathrm{~s}$, with each cycle increased by $0.5^{\circ} \mathrm{C}$. Specific amplification was confirmed by a single peak in the melting curve. The reactions for each target gene were performed in triplicate and the same PCR run.

Table 1. Reference genes, qPCR primers, and reaction parameters.

\begin{tabular}{|c|c|c|c|c|}
\hline Loci* $^{*}$ & Forward Primer $\left(5^{\prime}>3^{\prime}\right)$ & Reverse Primer $\left(5^{\prime}>3^{\prime}\right)$ & $\begin{array}{l}\text { Amplicon Size } \\
\text { (bp) }\end{array}$ & $\begin{array}{c}\text { Q-PCR Linear } \\
\text { Correlation } \\
\text { Coefficient }\end{array}$ \\
\hline AFE_2126 (NRAMP) & CTCTGGTGGTGCTGATTC & ATGAATATGGAAGCGATTACCT & 76 & 1.000 \\
\hline AFE_2475 (gmk) & GATGCGTTAGCCGACTTG & ACTGTTAATACCGAGGAGATTC & 108 & 1.000 \\
\hline AFE_2714 (rplL) & TGGAAGAACAGACCGAAT & AGACCAAGACCAGTGATG & 97 & 0.999 \\
\hline AFE_2150 (gyrA) & CGTATCGCCATTGAACTC & TTGATATTGAACACGCTCTG & 95 & 0.997 \\
\hline AFE_2711 (rpoC) & GGTGAACGCTATAACAAG & TACACGGTATCCTTACTG & 95 & 0.999 \\
\hline
\end{tabular}

The reverse-transcribed product (cDNA) 10-fold dilutions (ranging from $10^{-4}$ to $10^{-9}$ ) were used to generate a 6-point standard curve for every gene by using the quantification cycle $\left(\mathrm{C}_{\mathrm{q}}\right.$, previously known as the threshold cycle $\left(C_{t}\right)$ ) value versus the logarithm of each dilution factor. Transcript quantities were calculated from the standard curve by the software accompanying the iCycler $\mathrm{iQ}$ real-time PCR detection System (Bio-Rad) set with default parameters. Each experiment included no template control, a negative control (RNA template), and a positive control (DNA template). Every sample was performed in triplicate.

\subsection{Bioinformatic Analysis}

A candidate Nramp gene of At. ferrooxidans DC was sequenced and identified by BLASTP (http://blast.ncbi.nlm.nih.gov/Blast.cgi). The translated protein was further characterized using the following bioinformatics software or tools available online: primary structure identity and similarity by ClustalX 2.0 and the weblogo server (http://weblogo.berkeley.edu/logo.cgi), subcellular localization by the PSORTb v.3.0 server (http://www.psort.org/psortb/index.html), transmembrane protein analysis by the TMHMM v2.0 server (http://www.cbs.dtu.dk/services/TMHMM-2.0/), and transport motif recognition (http://myhits.isb-sib.ch/cgi-bin/motif_scan).

\subsection{Expression Stability of Candidate Reference Genes}

According to the methods of Vandesompele and Andersen implemented in the Visual Basic Application geNorm, the expression of the 7 selected reference genes (map, gmk, rplL, gyrA, recA, era, and $r p o C$ ) [40] at six different $\mathrm{Fe}^{2+}$ concentration were analyzed. A value of $\mathrm{M}$ results in a rank, where the best genes are those with the lowest $M$ value [41]. TIGRFAMs were used to classify the reference genes by function (Table 2) [42]. Relative gene expression levels were normalized based on multiple reference genes. The $\Delta \Delta \mathrm{Ct}$-based method (GeNorm software) was used to normalize the expression of AFE_2126 by correlating their $\mathrm{Ct}$ values of samples grown in the presence of different concentrations of ferrous iron to the $\mathrm{Ct}$ values of the reference genes. 
Table 2. The characteristics of seven candidate reference genes from At. ferrooxidans DC.

\begin{tabular}{|c|c|c|c|c|}
\hline TIGR Locus & Gene Symbol & Common Name TIGR & Biological Process & Functional Category \\
\hline AFE_2121 & map & methionine aminopeptidase, type I & Protein processing & Protein posttranslational modification \\
\hline AFE_2475 & gmk & guanylate kinase & Energetic and intermediary metabolism & Biosynthesis of nucleotides \\
\hline AFE_2714 & rplL & ribosomal protein L7/L12 & Protein processing & Synthesis and modification of ribosomal proteins: \\
\hline AFE_2150 & gyrA & DNA gyrAse, A subunit & DNA Metabolism & Basic replication machinery \\
\hline AFE_2114 & recA & rec $A$ protein & DNA Metabolism & DNA replication, recombination, and repair \\
\hline AFE_1680 & era & GTP-binding protein Era & RNA Metabolism & Translation: ribosome function, maturation, and modification \\
\hline AFE_2711 & rpoC & DNA-directed RNA polymerase, $\beta$ subunit & RNA Metabolism & Basic transcription machinery \\
\hline
\end{tabular}

The Institute for Genomic Research (TIGR). 


\subsection{Nucleotide Sequence Accession Number}

The nucleotide sequence of the AFE_2126 gene and 7 selected reference genes (map, gmk, rplL, gyrA, recA, era, and rpoC) from At. ferrooxidans DC reported in this paper have been deposited in the National Center of Biotechnology Information of America nucleotide sequence database with accession numbers KC677728, KJ854561, KJ854563, KJ854559, KJ854562, KJ854560, KJ854557, and KJ854558.

\section{Results}

\subsection{Identification and Sequencing of AFE_2126 Gene from At. Ferrooxidans DC}

At. ferrooxidans DC was confirmed as At. ferrooxidans by the 16S ribosomal RNA gene (gi:209405433) fragment comparison with At. ferrooxidans ATCC23270 (gi:28194033). Based on the sequence of the At. ferrooxidans ATCC 23270 chromosome, two primers, F1 and R1, were designed to amplify the putative open reading frame (ORF) encoding AFE_2126 from the genomic DNA of At. ferrooxidans DC. The amplified product was purified and confirmed by DNA sequencing. The results showed that AFE_2126 has a predicted length of $1371 \mathrm{nt}$ ORF, encoding 456 amino acid residues (molecular mass $49.5 \mathrm{ku}$ ), and an isoelectric point of 6.55. It contains 24 acidic amino acids, 32 basic, 94 polar, and 306 nonpolar, covering 19 kinds of amino acids but Cys (cysteine). The percentages were calculated as $5.3 \%$ acidic residues, $7.0 \%$ basic, $20.6 \%$ polar, and $67.1 \%$ nonpolar.

\subsection{Bioinformatic Analysis of the AFE_2126 from At. Ferrooxidans DC}

Ten sequences were aligned with AFE_2126 amino acid sequences in At. ferrooxidans DC, by use of the Vector NTI Advance 10, and scores were calculated for pairwise comparisons (Table 3). Five expressed sequence tags from extreme acidophile (Acidithiobacillus ferrooxidans ATCC 53993, Acidithiobacillus ferrooxidans ATCC 23270, Alicyclobacillus acidocaldarius LAA1, Acidiphilium cryptum JF5, and Candidatus Methanosphaerula palustris E19c) were identified that share considerable identity with AFE_2126 amino acid sequences $(100 \%, 88 \%, 60 \%, 52 \%$, and $43 \%$, respectively). However, another five expressed sequence tags from moderate bacteria (Escherichia coli O111:H-str. 11128), plants (Arabidopsis thaliana), yeast (Saccharomyces cerevisiae S288c), mouse (NRAMP1), and homo sapiens (NRAMP2) were identified that share identity with AFE_2126 amino acid sequences in the range of $15-20 \%$. A transmembrane protein analysis indicated that the N-terminus of AFE_2126 was cytoplasmic and followed by 11 transmembrane segments and that the C-terminus was periplasmic, together with the loops between transmembrane segments (TMS)1/2, 3/4, 5/6, 7/8, and 9/10 (Figure 1). After transport motif recognition, there was a conserved transport motif (5'-QVIASIFMPAAMLFLLMLLNDREIMGSYVNRR-3') in the AFE_2126 protein sequence from At. ferrooxidans DC, common among NRAMP homologs [43], and an intracytoplasmic consensus transport signature between transmembrane segments 10 and 11 . The subcellular localization of the AFE_2126 protein was predicted to lie in the cytoplasmic membrane (Supplementary File S1) based on analysis by the PSORTb v.3.0 server [44] and its sequence indicated the presence of eleven internal helices (Figure 1 and Supplementary File S2) by the TMHMM v2.0 server [45]. 
Table 3. Percent similarity and identity (in parentheses) scores were calculated between AFE_2126 from At. ferrooxidans of the Dachang Copper Mine (DC) and Nramp-related proteins.

\begin{tabular}{|c|c|c|c|}
\hline GI Number & Organisms & $\begin{array}{c}\text { Protein Symbol and Protein } \\
\text { Description }\end{array}$ & Similarity \\
\hline gi:218667514 (456 aa) & Acidithiobacillus ferrooxidans ATCC 23270 & NRAMP family & $100(100)$ \\
\hline gi:198282304 (456 aа) & Acidithiobacillus ferrooxidans ATCC 53993 & NRAMP family & $95(88)$ \\
\hline gi:218288940 (448 aа) & Alicyclobacillus acidocaldarius LAA1 & NRAMP family & $75(60)$ \\
\hline gi:148244067 (457 aa) & Acidiphilium cryptum JF5 & NRAMP family & $72(52)$ \\
\hline gi:219850775 (425 aа) & $\begin{array}{l}\text { Candidatus Methanosphaerula palustris } \\
\text { E19c }\end{array}$ & NRAMP family & $64(43)$ \\
\hline gi:260869095 (412 aa) & Escherichia coli O111:H-str. 11128 & $\begin{array}{c}\text { manganese/divalent cation transporter } \\
\text { MntH }\end{array}$ & $40(20)$ \\
\hline $\begin{array}{l}\text { gi: } 6468012 \\
\text { (509 aa) }\end{array}$ & Arabidopsis thaliana & metal transporter Nramp3 & $36(17)$ \\
\hline $\begin{array}{l}\text { gi:6321841 } \\
\text { (549 aa) }\end{array}$ & Saccharomyces cerevisiae S288c & $\begin{array}{c}\text { Smf2 (probable NRAMP divalent cation } \\
\text { transporter) }\end{array}$ & $35(18)$ \\
\hline gi:295293167 (590 aа) & Homo sapiens & $\begin{array}{l}\text { Nramp2 (multiple divalent cation } \\
\text { transporter for } \mathrm{Fe}^{2+}, \mathrm{Mn}^{2+} \text {, and } \mathrm{Zn}^{2+} \text { ) }\end{array}$ & $34(18)$ \\
\hline $\begin{array}{l}\text { gi:730193 } \\
\text { (548 aa) }\end{array}$ & Mouse & $\begin{array}{l}\text { Nramp1, divalent transition metal (iron } \\
\text { and manganese) transporter }\end{array}$ & $32(17)$ \\
\hline
\end{tabular}

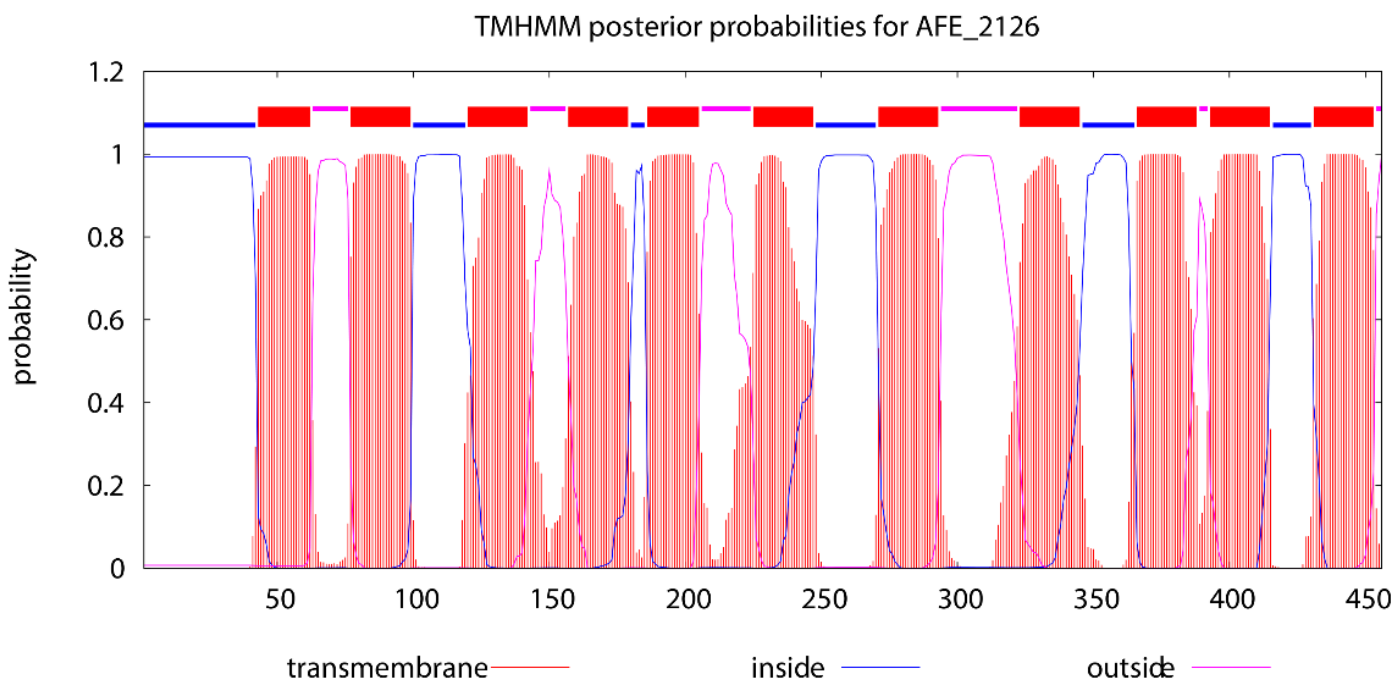

Figure 1. TMHMM posterior probabilities predictions for the transmembrane helices of the AFE_2126 protein from At. ferrooxidans of the Dachang Copper Mine (DC). A transmembrane protein analysis indicated that the N-terminus of AFE_2126 was cytoplasmic and followed by 11 transmembrane segments and that the $\mathrm{C}$-terminus was periplasmic, together with the loops between transmembrane segments (TMS)1/2,3/4,5/6,7/8, and 9/10.

\subsection{Prediction of Conserved Sites and Domains of the NRAMP Homolog}

Multiple sequence alignment analysis revealed that there were many conserved sites and domains (Figure 2). As shown in Figure 2a, TMS1 (transmembrane segments) contained a motif GP(G/A). The predicted extracytoplasmic loop 1 (between TM1 and TM2) contains the Nramp conserved motif D(P/A)G(N/G) (Figure 2b). Motif DAGG extracytoplasmic loop 1 existed in At. ferrooxidans DC and most prokaryotes, and motif DPGN existed in most eukaryotes and few prokaryotes (Supplementary File S3). Intracytoplasmic loop 2 contained a motif $\mathrm{Qx}(\mathrm{L} / \mathrm{M}) \times x x x G x x T x x x(\mathrm{~L} / \mathrm{H}) \times x x(\mathrm{C} / \mathrm{I})$ (Figure 2c), extracytoplasmic loop 2 contained a motif E(V/F)xG (Figure 2d), and TMS 6 contained a motif GxxxxP(H/W)xx(F/Y) (Figure 2e).

Multiple sequence alignment analysis revealed that there were many conserved sites and domains (Figure 2), which may be provided with specific roles. Some of them were studied and clarified by some authors, and the others were unclear in function. After multiple sequence alignments from bacteria to humans, the results showed that there were many invariant and variant sites, which may be important for the function of iron transport and the apparent transporter affinity for $\mathrm{H}^{+}$. 


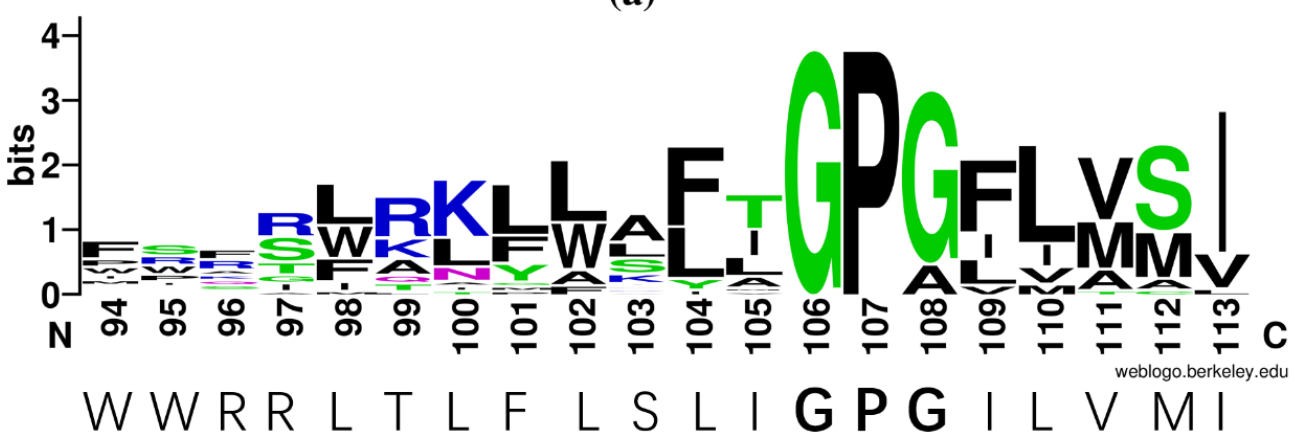

(b)

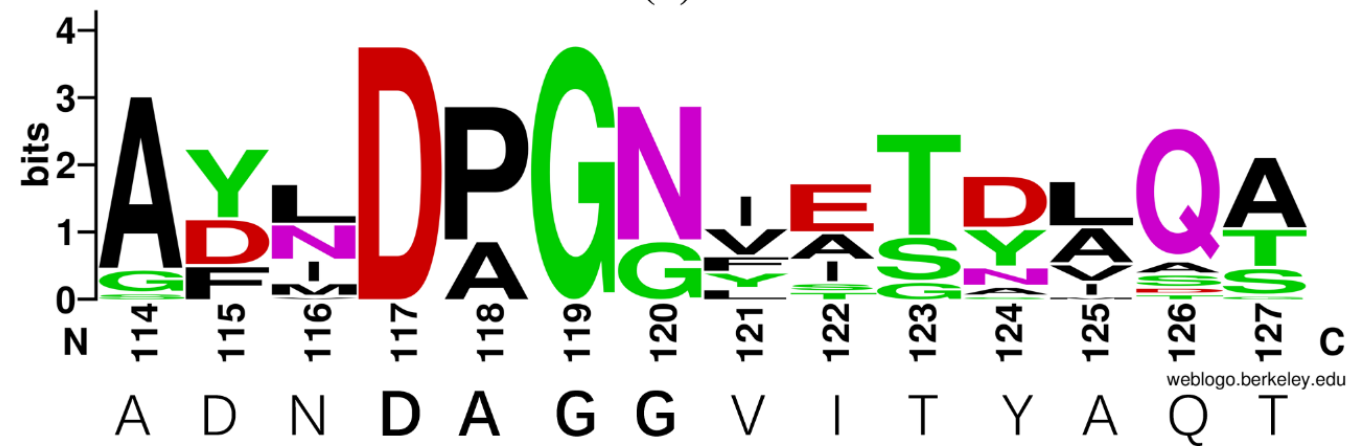

(c)

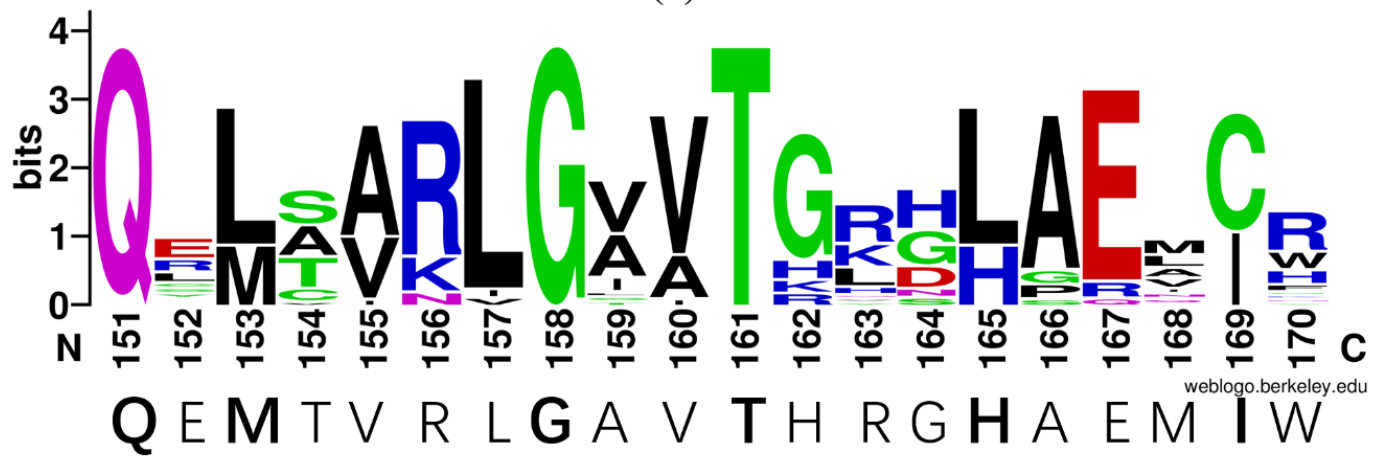

(d)

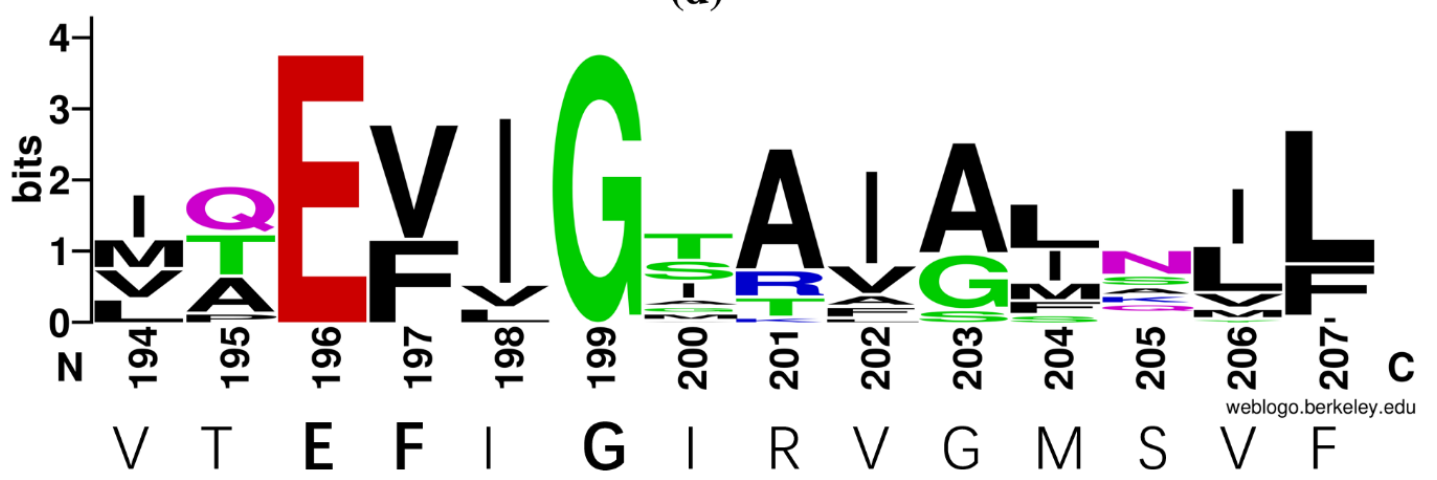

Figure 2. Cont. 
(e)

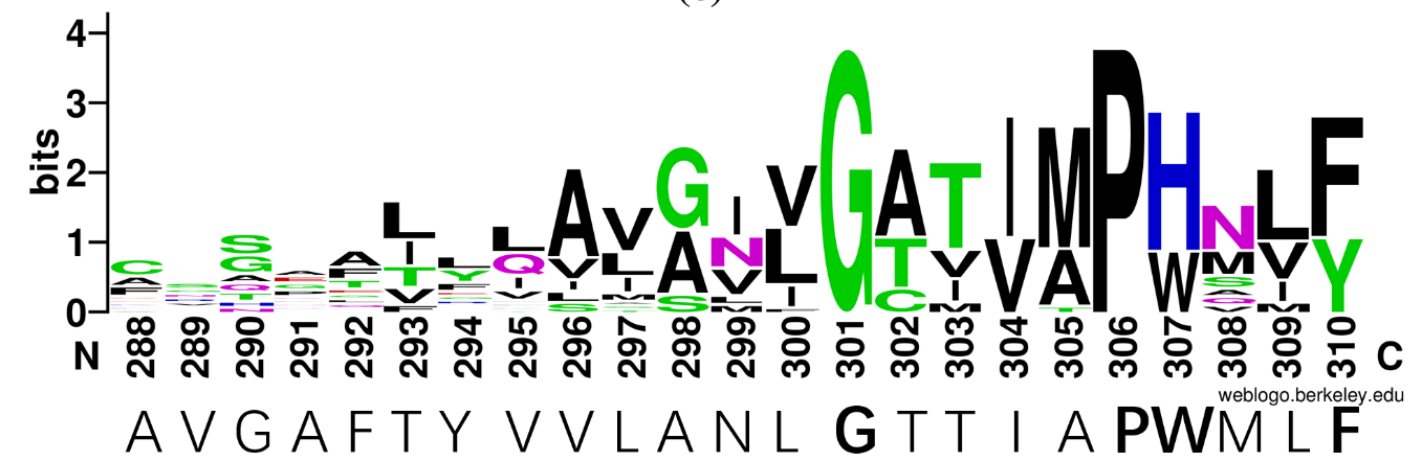

Figure 2. Comparison of the web logos of the Nramp family from bacteria to humans. All the logos are based on an alignment of 26 sequences (Supplementary File S3). The height of the entire vertical axis is 4 bits for all the logos. Specific sites of At. ferrooxidans DC are indicated by boldface letters in each picture bottom. (a) TM1, (b) extracytoplasmic loop 1, (c) intracytoplasmic loop 2, (d) extracytoplasmic loop 2, and (e) TM6.

\subsection{Selection and Evaluation of Reference Genes}

We studied the mRNA expression levels of seven candidate reference genes from At. ferrooxidans DC in six different $\mathrm{Fe}^{2+}$ concentrations using RT-qPCR and evaluated their expression stabilities. In short, the geNorm method is based on the pairwise comparison method. It depends on the calculation of an $\mathrm{M}$ value, which is defined as the average pairwise variation of a particular gene from all other genes [41]. The $\mathrm{M}$ values are less than 1.5, which satisfy the requirements for the stability evaluation of the candidate reference genes (Supplementary File S4). According to geNorm, era, gmk, and $r p o C$ showed the least variability in expression in all conditions evaluated (Supplementary File S5). Descending order of the expression stabilities was era, gmk, rpoC, gyrA, recA, map, and rplL. We chose the first three candidate reference genes (era, gmk, and rpoC) as reference genes of this study to ensure the results were more reliable.

\subsection{Expression of NRAMP in At. Ferrooxidans DC in Different Growth Conditions}

RT-qPCR experiment was designed to measure NRAMP mRNA levels. We chose three candidate reference mRNA (era, gmk, and rpoC) as reference genes to normalize the expression of AFE_2126 mRNA, because they showed the least variability in ferrous iron concentrations. Then, we got a different expression level of AFE_2126 mRNA in different ferrous iron concentrations. In order to easily identify the change trends, we set the minimum value as one and others greater than one (Figure 3). Figure 3 shows that, when the ferrous iron concentration was $600 \mathrm{mM}$, the expression level of AFE_2126 mRNA was the least. The relative expression of different ferrous ion concentrations: $300 \mathrm{mM}, 100 \mathrm{mM}, 10 \mathrm{mM}, 1 \mathrm{mM}$, and $0 \mathrm{mM}$, compared to $600 \mathrm{mM}$, were 1.1, 2.3, 11.7, 13.6, and 18.5-fold, respectively (Figure 3 and Supplementary File S6). The results showed that AFE_2126 mRNA levels in At. ferrooxidans DC were upregulated in response to decreases in the ambient $\mathrm{Fe}^{2+}$. According to an unpaired $t$-test at $95 \%$ confidence, we found that there was no significant change in the relative expressions at growth conditions of $600-\mathrm{mM}$ and $300-\mathrm{mM}$ ferrous ion concentrations. The ferrous ion concentration may be too high, indicating that it was no longer the limiting factor for bacterial growth. Instead, it became a toxic factor, which limited the expression of ferrous ion uptake genes. 


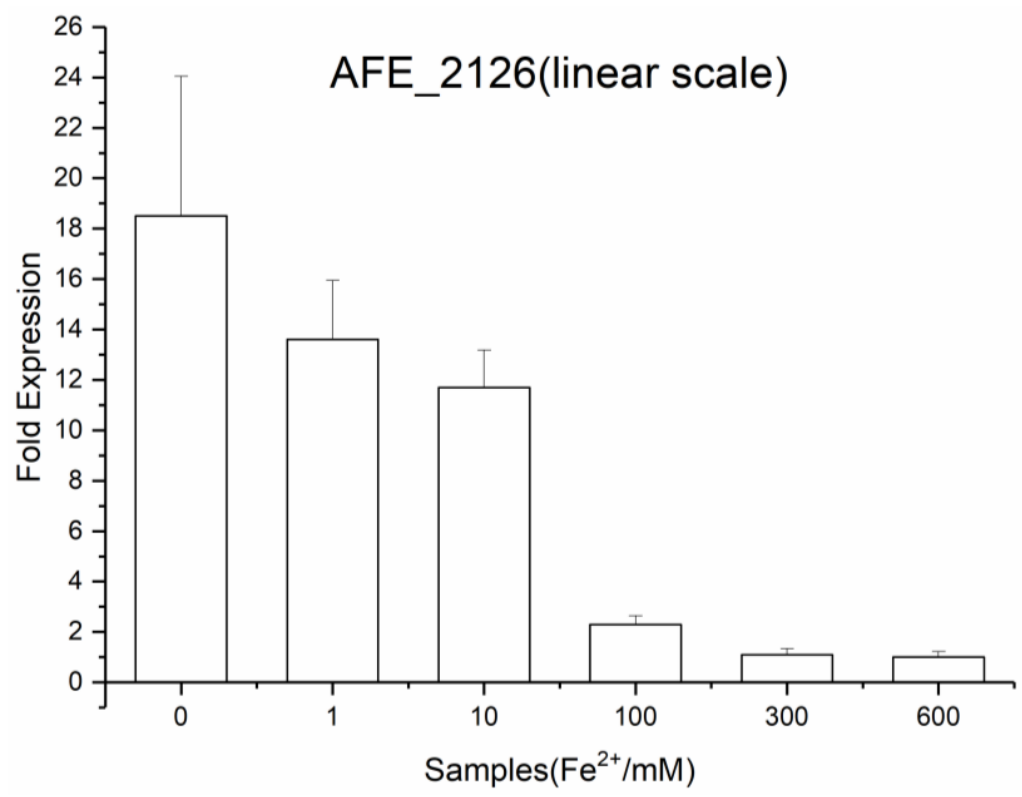

Figure 3. RT-qPCR analysis of the expression profile of AFE_2126 in response to different concentrations of ferrous ion $\left(\mathrm{Fe}^{2+}\right)$. Data are shown as relative expressions compared to the pooled cDNA sample (the highest concentration of ferrous ion) used as the reference for the microarray experiment. The relative expressions of different ferrous ion concentrations: $600 \mathrm{mM}, 300 \mathrm{mM}, 100 \mathrm{mM}, 10 \mathrm{mM}, 1 \mathrm{mM}$, and $0 \mathrm{mM}$ were $1,1.1,2.3,11.7,13.6$, and 18.5.

\section{Discussion}

\subsection{The AFE_2126 Protein Belongs to the NRAMP Family of Membrane Transporters}

The NRAMP family is a novel family of functionally related proteins that is defined by a common conserved hydrophobic core of ten transmembrane domains and either one or two nonconserved, highly hydrophobic TM domains $[43,46]$. The AFE_2126 protein sequence indicated the presence of eleven internal helices. AFE_2126 amino acid sequences share identity with eukaryotes in the range of 15-20\%. Still, they have many remote homologies based on discrete sequence motifs, which are highly conserved between many members of the Nramp family (Figure 2). On the basis of these analyses, it is proposed that the AFE_2126 protein belongs to the NRAMP family of membrane transporters.

\subsection{AFE_2126 Protein has Many Conserved Motifs Associated with Metal Ion Transport}

The predicted extracytoplasmic loop 1 (between TM1 and TM2) contains the Nramp conserved motif $\mathrm{D}(\mathrm{P} / \mathrm{A}) \mathrm{G}(\mathrm{N} / \mathrm{G})$ (Figure 2), which is of importance for the proper function of the transporter [7]. When DMT1 residue Gly ${ }^{88}$ was replaced by Ala, it led to abolishing both the $\mathrm{Me}^{2+}$ uptake $\left({ }^{55} \mathrm{Fe}^{2+}\right.$, ${ }^{54} \mathrm{Mn}^{2+}$ and ${ }^{60} \mathrm{Co}^{2+}$ ) and metal-state currents [47]. The motif DAGG extracytoplasmic loop 1 existed in At. ferrooxidans DC and most prokaryotes, and motif DPGN existed in most eukaryotes and few prokaryotes (Supplementary File S3). As shown in Figure 2, TMS1 (transmembrane segments) contained a motif $\mathrm{GP}(\mathrm{G} / \mathrm{A})$, the extracytoplasmic loop 2 contained a motif $\mathrm{E}(\mathrm{V} / \mathrm{F}) \mathrm{xG}$, TMS 6 contained a motif $G \operatorname{xxxP}(\mathrm{H} / \mathrm{W}) \times x(F / Y)$, and intracytoplasmic loop 2 contained a motif

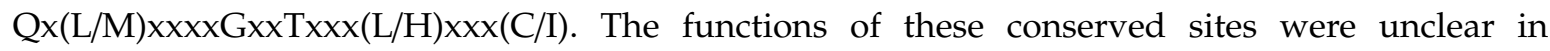
At. ferrooxidans DC, so the function will be studied through mutagenesis approaches and a toxicity assay [48] in the future.

\subsection{AFE_2126 Protein Mediates the Uptake of $\mathrm{Fe}^{2+}$}

The results showed that AFE_2126 mRNA levels in At. ferrooxidans DC were upregulated in response to decreases in the ambient $\mathrm{Fe}^{2+}$. Navarro et al. [49] suggested that the gene coded for 
the potential efflux system, due to the increase of gene expressions with the rise of the metal ion concentrations. In contrast, the results in Figure 3 suggest that AFE_2126 is more probably related to a $\mathrm{Fe}^{2+}$ import protein rather than to a $\mathrm{Fe}^{2+}$ efflux protein, as had been previously proposed through a bioinformatic prediction and in the reports of other organisms [50]. The cytoplasmic membrane expression of mRNA is increased in iron deficiency, which indicates that the microorganisms take up necessary iron to maintain the normal metabolism of life by increasing the expression of specific functional genes to survive. In the future, we will use the markerless mutagenesis strategy [51,52] to further verify the function of AFE_2126 through the mutant responses under various ferrous ion stresses.

\subsection{AFE_2126 Protein is a Symporter of $\mathrm{H}^{+}$and Iron $\left(\mathrm{Fe}^{2+}\right)$}

As known to all, the growth-medium $\mathrm{pH}$ of At. ferrooxidans is between 1.5-2.5 [20,53], while the periplasm $\mathrm{pH}$ is around 3.5 [54], and the cytoplasm $\mathrm{pH}$ is thought to be 6.5 [20]. The AFE_2126 gene was predicted to lie in the cytoplasmic membrane (between the cytoplasm and the periplasm). From the results of these analysis, it suggests that AFE_2126 functions to transport $\mathrm{Fe}^{2+}$ from the periplasm to the cytoplasm (Figure 4). Overall, these results also conclude that $\mathrm{Fe}^{2+}$ is transported in the direction identical to that of the $\mathrm{H}^{+}$gradient, i.e., symport (Figure 4), as demonstrated for Nramp2 [55], rather than antiport, as demonstrated for Nramp1 in Xenopus laevis [56]. This finding is consistent with the function in the iron transport from the acidified lumen of the endosomes into the cytoplasm [57]. In this case, the energy transported is provided by an electrochemical proton gradient, rather than directly driven by ATP hydrolysis [58,59]. For the Nramp1 function, ATP hydrolysis is maintained by the activity of the vesicular ATPase [60]. In the normally acidic late-endosomal/lysosomal compartment, Nramp1's function is to transport $\mathrm{Fe}^{2+}$ and other metal ions from a high $\mathrm{pH}$ (cytoplasmic) to a low $\mathrm{pH}$ (intravesicular) [56]. Unusually, the proton uptake drives cation symports [60]. Gu et al. [55] indicated that the cotransport of $\mathrm{H}^{+}$could lead to a slight decrease of $\mathrm{pH}$ on the inner membrane surface, resulting in maintaining the dissolution of iron before its binding to intracellular proteins. The transfer of ferrous iron into cells may be used to synthesize functional materials such as magnetosomes $[34,61]$.

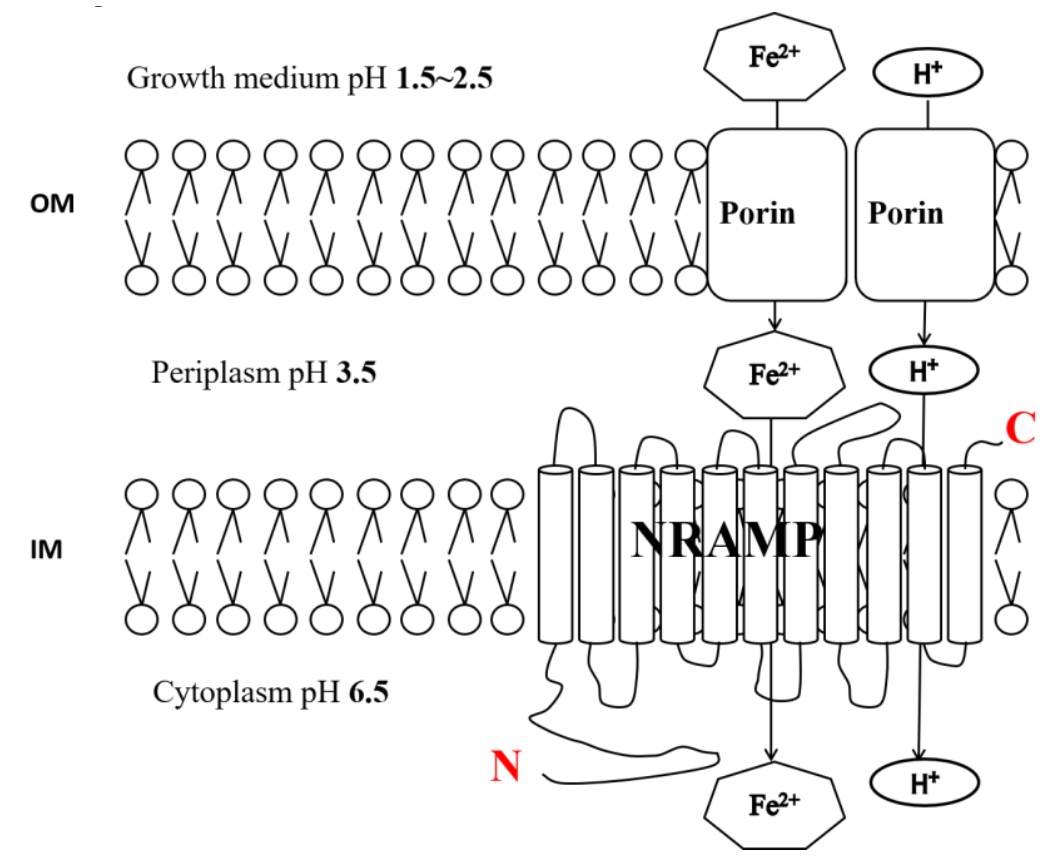

Figure 4. Proposed model for NRAMP-mediated $\mathrm{Fe}^{2+}$ uptake. $\mathrm{Fe}^{2+}$ and $\mathrm{H}^{+}$diffuse through the porins of the outer membrane (OM) and are subsequently transported into the cytoplasm by NRAMP anchored in the inner membrane (IM). 


\section{Conclusions}

After genome sequencing and sequence-similarity analyses, it is speculated that AFE_2126 of At. ferrooxidans DC belongs to the Nramp family, its N-terminus is cytoplasmic, followed by 11 transmembrane segments, and the C-terminus is periplasmic, and the loops between TMS1/2, 3/4, 5/6, $7 / 8$, and 9/10. The transporter property of AFE_2126 was studied by indirect measurement (RT-qPCR), and the results presented that AFE_2126 mRNA was upregulated in response to an iron deficiency, showing it can mediate the uptake of $\mathrm{Fe}^{2+}$. Based on the $\Delta \mathrm{pH}$ of the cytoplasmic membrane between the cytoplasm and the periplasm, it can be concluded that the AFE_2126 protein is a symporter of $\mathrm{H}^{+}$and iron $\left(\mathrm{Fe}^{2+}\right) . \mathrm{Fe}^{2+}$ and $\mathrm{H}^{+}$diffuse through the porins of the outer membrane $(\mathrm{OM})$ and are subsequently transported into the cytoplasm by NRAMP anchored in the inner membrane (IM). The establishment of its expression pattern in bacteria and its subcellular localization will help elucidate the function of the NRAMP protein in bacteria.

Supplementary Materials: The following are available online at http://www.mdpi.com/2075-163X/10/6/544/s1, S1. PSORTb v.3.0 server results. S2. TMHMM results. S3. CLUSTAL 2.0.12 MULTIPLE SEQUENCE ALIGNMENT. S4. The $\mathrm{M}$ value calculated from raw data by geNorm. S5. Expression stability of candidate reference genes. S6. Fold expression calculations.

Author Contributions: Conceptualization, B.M., X.L., and X.W.; data curation, B.M.; project administration, X.L. and X.W.; writing - original draft, B.M.; and writing-review and editing, L.S. and W.Z. All authors have read and agreed to the published version of the manuscript.

Funding: This research was funded by The National Key Basic Research Program of China, grant number 2010CB630901, the Natural Science Foundation of Hunan Province, grant number 2015JJ2165, and National Natural Science Foundation of China (31570113).

Conflicts of Interest: The authors declare no conflicts of interest.

\section{References}

1. Gruenheid, S.; Cellier, M.; Vidal, S.; Gros, P. Identification and characterization of a second mouse Nramp gene. Genomics 1995, 25, 514-525. [CrossRef]

2. Cellier, M.F.; Bergevin, I.; Boyer, E.; Richer, E. Polyphyletic origins of bacterial Nramp transporters. Trends Genet. 2001, 17, 365-370. [CrossRef]

3. Williams, L.E.; Pittman, J.K.; Hall, J.L. Emerging mechanisms for heavy metal transport in plants. Biochim. et Biophys. Acta 2000, 1465, 104-126. [CrossRef]

4. Vidal, S.; Belouchi, A.M.; Cellier, M.; Beatty, B.; Gros, P. Cloning and characterization of a second human NRAMP gene on chromosome 12q13. Mamm. Genome 1995, 6, 224-230. [CrossRef]

5. Bozzi, A.T.; Bane, L.B.; Weihofen, W.A.; Singharoy, A.; Guillen, E.R.; Ploegh, H.L.; Schulten, K.; Gaudet, R. Crystal structure and conformational change mechanism of a bacterial Nramp-family divalent metal transporter. Structure 2016, 24, 2102-2114. [CrossRef] [PubMed]

6. Yanatori, I.; Kishi, F. DMT1 and iron transport. Free. Radic. Biol. Med. 2019, 133, 55-63. [CrossRef] [PubMed]

7. Courville, P.; Chaloupka, R.; Cellier, M.F. Recent progress in structure-function analyses of Nramp proton-dependent metal-ion transporters. Biochem. Cell Biol. 2006, 84, 960-978. [CrossRef]

8. Peracino, B.; Wagner, C.; Balest, A.; Balbo, A.; Pergolizzi, B.; Noegel, A.A.; Steinert, M.; Bozzaro, S. Function and mechanism of action of Dictyostelium Nramp1 (Slc11a1) in bacterial infection. Traffic 2006, 7, 22-38. [CrossRef]

9. Lam-Yuk-Tseung, S.; Govoni, G.; Forbes, J.; Gros, P. Iron transport by Nramp2/DMT1: pH regulation of transport by 2 histidines in transmembrane domain 6. Blood 2003, 101, 3699-3707. [CrossRef]

10. Cohen, A.; Nelson, H.; Nelson, N. The family of SMF metal ion transporters in yeast cells. J. Biol. Chem. 2000, 275, 33388-33394. [CrossRef] [PubMed]

11. Vidal, S.M.; Malo, D.; Vogan, K.; Skamene, E.; Gros, P. Natural resistance to infection with intracellular parasites: Isolation of a candidate for Bcg. Cell 1993, 73, 469-485. [CrossRef]

12. Li, J.; Wang, L.; Zheng, L.; Wang, Y.; Chen, X.; Zhang, W. A functional study identifying critical residues involving metal transport activity and selectivity in natural resistance-associated macrophage protein 3 in Arabidopsis thaliana. Int. J. Mol. Sci. 2018, 19, 1430. [CrossRef] [PubMed] 
13. Curie, C.; Alonso, J.M.; Le Jean, M.; Ecker, J.R.; Briat, J.F. Involvement of NRAMP1 from Arabidopsis thaliana in iron transport. Biochem. J. 2000, 347 Pt 3, 749-755. [CrossRef]

14. Thomine, S.; Wang, R.; Ward, J.; Crawford, N.; Schroeder, J. Cadmium and iron transport by members of a plant metal transporter family in Arabidopsis with homology to Nramp genes. Proc. Natl. Acad. Sci. USA 2000, 97, 4991-4996. [CrossRef]

15. Agranoff, D.; Monahan, I.M.; Mangan, J.A.; Butcher, P.D.; Krishna, S. Mycobacterium tuberculosis expresses a novel $\mathrm{pH}$-dependent divalent cation transporter belonging to the Nramp family. J. Exp. Med. 1999, 190, 717-724. [CrossRef] [PubMed]

16. Osorio, H.; Martinez, V.; Veloso, F.A.; Pedroso, I.; Valdes, J.; Jedlicki, E.; Holmes, D.S.; Quatrini, R. Iron homeostasis strategies in acidophilic iron oxidizers: Studies in Acidithiobacillus and Leptospirillum. Hydrometallurgy 2008, 94, 175-179. [CrossRef]

17. Mangold, S.; Potrykus, J.; Bjorn, E.; Lovgren, L.; Dopson, M. Extreme zinc tolerance in acidophilic microorganisms from the bacterial and archaeal domains. Extremophiles 2013, 17, 75-85. [CrossRef] [PubMed]

18. Potrykus, J.; Jonna, V.R.; Dopson, M. Iron homeostasis and responses to iron limitation in extreme acidophiles from the Ferroplasma genus. Proteomics 2011, 11, 52-63. [CrossRef] [PubMed]

19. Ai, C.B.; Yan, Z.; Chai, H.S.; Gu, T.Y.; Wang, J.J.; Chai, L.Y.; Qiu, G.Z.; Zeng, W.M. Increased chalcopyrite bioleaching capabilities of extremely thermoacidophilic Metallosphaera sedula inocula by mixotrophic propagation. J. Ind. Microbiol. Biot. 2019, 46, 1113-1127. [CrossRef]

20. Rawlings, D.E. Characteristics and adaptability of iron- and sulfur-oxidizing microorganisms used for the recovery of metals from minerals and their concentrates. Microb. Cell Factories 2005, 4, 13. [CrossRef] [PubMed]

21. Zhang, Y.; Zhao, H.; Zhang, Y.; Liu, H.; Yin, H.; Deng, J.; Qiu, G. Interaction mechanism between marmatite and chalcocite in acidic (microbial) environments. Hydrometallurgy 2020, 191, 105217. [CrossRef]

22. Ma, L.; Wang, X.; Feng, X.; Liang, Y.; Xiao, Y.; Hao, X.; Yin, H.; Liu, H.; Liu, X. Co-culture microorganisms with different initial proportions reveal the mechanism of chalcopyrite bioleaching coupling with microbial community succession. Bioresour. Technol. 2017, 223, 121-130. [CrossRef] [PubMed]

23. Ma, L.Y.; Wang, X.J.; Tao, J.M.; Feng, X.; Zou, K.; Xiao, Y.H.; Liang, Y.L.; Yin, H.Q.; Liu, X.D. Bioleaching of the mixed oxide-sulfide copper ore by artificial indigenous and exogenous microbial community. Hydrometallurgy 2017, 169, 41-46. [CrossRef]

24. Gao, X.Y.; Liu, X.J.; Fu, C.A.; Gu, X.F.; Lin, J.Q.; Liu, X.M.; Pang, X.; Lin, J.Q.; Chen, L.X. Novel strategy for improvement of the bioleaching efficiency of Acidithiobacillus ferrooxidans based on the AfeI/R quorum sensing system. Minerals-Basel 2020, 10, 222. [CrossRef]

25. Ai, C.; Liang, Y.; Miao, B.; Chen, M.; Zeng, W.; Qiu, G. Identification and analysis of a novel gene cluster involves in $\mathrm{Fe}^{2+}$ oxidation in Acidithiobacillus ferrooxidans ATCC 23270, a typical biomining acidophile. Curr. Microbiol. 2018, 75, 818-826. [CrossRef]

26. Liu, H.C.; Xia, J.L.; Nie, Z.Y.; Zheng, L.; Ma, C.Y.; Zhao, Y.D. Differential utilization and speciation transformation of orthorhombic alpha-S-8 and amorphous mu-S by substrate-acclimated mesophilic Acidithiobacillus ferrooxidans. Trans. Nonferrous Met. Soc. China 2015, 25, 3096-3102. [CrossRef]

27. Ma, L.; Wang, X.; Tao, J.; Feng, X.; Liu, X.; Qin, W. Differential fluoride tolerance between sulfur- and ferrous iron-grown Acidithiobacillus ferrooxidans and its mechanism analysis. Biochem. Eng. J. 2017, 119, 59-66. [CrossRef]

28. Braun, V.; Killmann, H. Bacterial solutions to the iron-supply problem. Trends Biochem. Sci. 1999, 24, 104-109. [CrossRef]

29. Touati, D. Iron and oxidative stress in bacteria. Arch. Biochem. Biophys. 2000, 373, 1-6. [CrossRef]

30. Velayudhan, J.; Hughes, N.J.; McColm, A.A.; Bagshaw, J.; Clayton, C.L.; Andrews, S.C.; Kelly, D.J. Iron acquisition and virulence in Helicobacter pylori: A major role for $\mathrm{FeoB}$, a high-affinity ferrous iron transporter. Mol. Microbiol. 2000, 37, 274-286. [CrossRef]

31. Schalk, I.J.; Yue, W.W.; Buchanan, S.K. Recognition of iron-free siderophores by TonB-dependent iron transporters. Mol. Microbiol. 2004, 54, 14-22. [CrossRef] [PubMed]

32. Chen, A.; Hao, X.; Xiao, Y.; Zou, K.; Liu, H.; Liu, X.; Yin, H.; Qiu, G.; Liang, Y. Responses of Acidithiobacillus thiooxidans A01 to Individual and Joint Nickel $\left(\mathrm{Ni}^{2+}\right)$ and Ferric $\left(\mathrm{Fe}^{3+}\right)$. Minerals-Basel 2019, 9, 82. [CrossRef] 
33. Zhang, S.; Yan, L.; Li, H.Y.; Liu, H.T. Optimal conditions for growth and magnetosome formation of Acidithiobacillus ferrooxidans. Afr. J. Microbiol. Res. 2012, 6, 6142-6151. [CrossRef]

34. Liu, W.B.; Wu, H.Y.; Liu, X.D.; Liu, X.X. Influence of different Fe sources and concentrations on formation of magnetosomes in Acidithiobacillus ferrooxidans. T. Nonferr. Metal Soc. 2008, 18, 1379-1385. [CrossRef]

35. Lin, W.; Pan, Y.; Bazylinski, D.A. Diversity and ecology of and biomineralization by magnetotactic bacteria. Environ. Microbiol. Rep. 2017, 9, 345-356. [CrossRef] [PubMed]

36. Su, Y.B.; Wang, F.X.; Zhang, J.; Tong, R.A.; Chong, S.K.; Wang, W.; Wang, C.A.; Chen, C.F. A monocrystal $\mathrm{Fe}_{3} \mathrm{O}_{4} @$ ultrathin N-doped carbon core/shell structure: From magnetotactic bacteria to Li storage. J. Mater. Chem. A 2019, 7, 20899-20904. [CrossRef]

37. Zhang, Y.; Wu, X.; Liu, D.; Duan, H.; Fan, H. Sequencing and bioinformatics analysis of the metal-related genes in Acidithiobacillus ferrooxidans strain DC. Folia Microbiol. (Praha) 2013, 58, 551-560. [CrossRef]

38. Silverman, M.P.; Lundgren, D.G. Studies on the chemoautotrophic iron bacterium Ferrobacillus ferrooxidans: I. An improved medium and a harvesting procedure for securing high cell yields. J. Bacteriol. 1959, 77, 642-647. [CrossRef]

39. Nolan, T.; Hands, R.; Bustin, S. Quantification of mRNA using real-time RT-PCR. Nat. Protoc. 2006, 1, 1559-1582. [CrossRef]

40. Pamela, N.; Paulo, C.; Eugenia, J.; David, H.; Raquel, Q. Selection and evaluation of reference genes for improved interrogation of microbial transcriptomes: Case study with the extremophile Acidithiobacillus ferrooxidans. BMC Mol. Biol. 2009, 10, 1-11. [CrossRef]

41. Vandesompele, J.; De Preter, K.; Pattyn, F.; Poppe, B.; Van Roy, N.; De Paepe, A.; Speleman, F. Accurate normalization of real-time quantitative RT-PCR data by geometric averaging of multiple internal control genes. Genome. Biol. 2002, 3, RESEARCH0034. [CrossRef] [PubMed]

42. Gil, R.; Silva, F.J.; Pereto, J.; Moya, A. Determination of the core of a minimal bacterial gene set. Microbiol. Mol. Biol. Rev. 2004, 68, 518-537. [CrossRef] [PubMed]

43. Cellier, M.; Prive, G.; Belouchi, A.; Kwan, T.; Rodrigues, V.; Chia, W.; Gros, P. Nramp defines a family of membrane proteins. Proc. Natl. Acad. Sci. USA 1995, 92, 10089-10093. [CrossRef] [PubMed]

44. Yu, N.Y.; Wagner, J.R.; Laird, M.R.; Melli, G.; Rey, S.; Lo, R.; Dao, P.; Sahinalp, S.C.; Ester, M.; Foster, L.J.; et al. PSORTb 3.0: Improved protein subcellular localization prediction with refined localization subcategories and predictive capabilities for all prokaryotes. Bioinformatics 2010, 26, 1608-1615. [CrossRef] [PubMed]

45. Moller, S.; Croning, M.D.R.; Apweiler, R. Evaluation of methods for the prediction of membrane spanning regions. Bioinformatics 2001, 17, 646-653. [CrossRef] [PubMed]

46. Nevo, Y.; Nelson, N. The NRAMP family of metal-ion transporters. Biochim. et Biophys. Acta 2006, 1763, 609-620. [CrossRef]

47. Cohen, A.; Nevo, Y.; Nelson, N. The first external loop of the metal ion transporter DCT1 is involved in metal ion binding and specificity. Proc. Natl. Acad. Sci. USA 2003, 100, 10694-10699. [CrossRef]

48. Bozzi, A.T.; Bane, L.B.; Weihofen, W.A.; McCabe, A.L.; Singharoy, A.; Chipot, C.J.; Schulten, K.; Gaudet, R. Conserved methionine dictates substrate preference in Nramp-family divalent metal transporters. Proc. Natl. Acad. Sci. USA 2016, 113, 10310-10315. [CrossRef]

49. Navarro, C.A.; Orellana, L.H.; Mauriaca, C.; Jerez, C.A. Transcriptional and functional studies of Acidithiobacillus ferrooxidans genes related to survival in the presence of copper. Appl. Environ. Microbiol. 2009, 75, 6102-6109. [CrossRef] [PubMed]

50. Wei, W.; Chai, T.; Zhang, Y.; Han, L.; Xu, J.; Guan, Z. The Thlaspi caerulescens NRAMP homologue TcNRAMP3 is capable of divalent cation transport. Mol. Biotechnol. 2009, 41, 15-21. [CrossRef]

51. van Zyl, L.J.; van Munster, J.M.; Rawlings, D.E. Construction of arsB and tetH mutants of the sulfur-oxidizing bacterium Acidithiobacillus caldus by marker exchange. Appl. Environ. Microbiol. 2008, 74, 5686-5694. [CrossRef] [PubMed]

52. Wang, H.Y.; Liu, X.M.; Liu, S.S.; Yu, Y.Y.; Lin, J.Q.; Lin, J.Q.; Pang, X.; Zhao, J. Development of a markerless gene replacement system for Acidithiobacillus ferrooxidans and construction of a pfkB mutant. Appl. Environ. Microbiol. 2012, 78, 1826-1835. [CrossRef] [PubMed]

53. Yu, Z.J.; Yu, R.L.; Liu, A.J.; Liu, J.; Zeng, W.M.; Liu, X.D.; Qiu, G.Z. Effect of pH values on extracellular protein and polysaccharide secretions of Acidithiobacillus ferrooxidans during chalcopyrite bioleaching. Trans. Nonferr Metal Soc China 2017, 27, 406-412. [CrossRef] 
54. Kai, M.; Yano, T.; Fukumori, Y.; Yamanaka, T. Cytochrome oxidase of an acidophilic iron-oxidizing bacterium, Thiobacillus ferrooxidans, functions at pH 3.5. Biochem. Biophys. Res Commun. 1989, 160, 839-843. [CrossRef]

55. Gunshin, H.; Mackenzie, B.; Berger, U.V.; Gunshin, Y.; Romero, M.F.; Boron, W.F.; Nussberger, S.; Gollan, J.L.; Hediger, M.A. Cloning and characterization of a mammalian proton-coupled metal-ion transporter. Nature 1997, 388, 482-488. [CrossRef] [PubMed]

56. Goswami, T.; Bhattacharjee, A.; Babal, P.; Searle, S.; Moore, E.; Li, M.; Blackwell, J.M. Natural-resistance-associated macrophage protein 1 is an $\mathrm{H}^{+}$/bivalent cation antiporter. Biochem. J. 2001, 354, 511-519. [CrossRef] [PubMed]

57. Garrick, M.D.; Gniecko, K.; Liu, Y.; Cohan, D.S.; Garrick, L.M. Transferrin and the transferrin cycle in Belgrade rat reticulocytes. J. Biol. Chem. 1993, 268, 14867-14874.

58. Nelson, N. Energizing porters by proton-motive force. J. Exp. Biol. 1994, 196, 7-13.

59. Ehrnstorfer, I.A.; Manatschal, C.; Arnold, F.M.; Laederach, J.; Dutzler, R. Structural and mechanistic basis of proton-coupled metal ion transport in the SLC11/NRAMP family. Nat. Commun. 2017, 8, 14033. [CrossRef]

60. Nelson, N.; Sacher, A.; Nelson, H. The significance of molecular slips in transport systems. Nat. Rev. Mol. Cell Biol. 2002, 3, 876-881. [CrossRef]

61. Wu, L.B.; Yang, B.J.; Wang, X.X.; Wu, B.Q.; He, W.L.; Gan, M.; Qiu, G.Z.; Wang, J. Effects of single and mixed energy sources on intracellular nanoparticles synthesized by Acidithiobacillus ferrooxidans. Minerals-Basel 2019, 9, 163. [CrossRef]

(C) 2020 by the authors. Licensee MDPI, Basel, Switzerland. This article is an open access article distributed under the terms and conditions of the Creative Commons Attribution (CC BY) license (http://creativecommons.org/licenses/by/4.0/). 